\title{
Statement of Basis/Proposed Plan for the Gunsite 720 Rubble Pit Unit (631-18G)
}

by

E. Palmer

Westinghouse Savannah River Company

Savannah River Site

Aiken, South Carolina 29808

DOE Contract No. DE-AC09-89SR18035

This paper was prepared in connection with work done under the above contract number with the U.S.

Department of Energy. By acceptance of this paper, the publisher and/or recipient acknowledges the U.S. Government's right to retain a nonexclusive, royalty-free license in and to any copyright covering this paper, along with the right to reproduce and to authorize others to reproduce all or part of the copyrighted paper.
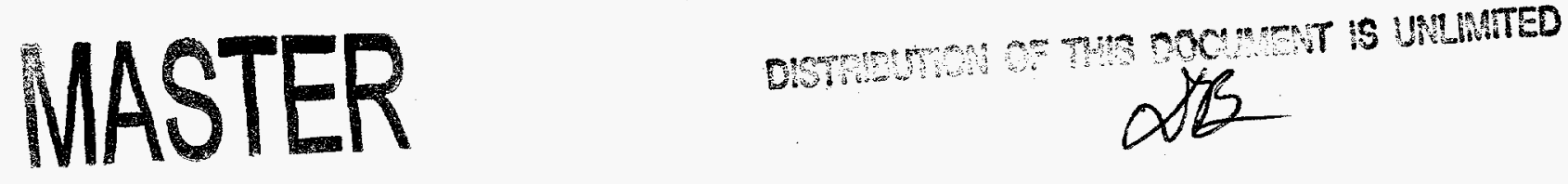


\section{United States Department of Energy Savannah River Site}

WSRC-RP-96-217

Revision 1 (changes in boldface)

July 8, 1996
RECEIVED

J4น 161998

OSTI

Prepared by:

Westinghouse Savannah River Company

Savannah River Site

Aiken, South Carolina 29808

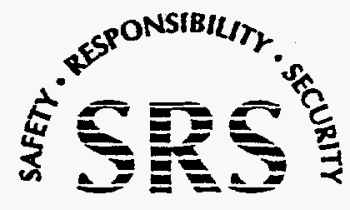




\section{DISCLAIMER}

This report was prepared as an account of work sponsored by an agency of the United States Government. Neither the United States Government nor any agency thereof, nor any of their employees, makes any warranty, express or implied, or assumes any legal liability or responsibility for the accuracy, completeness, or usefulness of any information, apparatus, product, or process disclosed, or represents that its use would not infringe privately owned rights. Reference herein to any specific commercial product, process, or service by trade name, trademark, manufacturer, or otherwise does not necessarily constitute or imply its endorsement, recommendation, or favoring by the United States Government or any agency thereof. The views and opinions of authors expressed herein do not necessarily state or reflect those of the United States Government or any agency thereof.

This report has been reproduced directly from the best available copy.

Available to DOE and DOE contractors from the Office of Scientific and Technical Information, P.O. Box 62, Oak Ridge, TN 37831; prices available from (615) 576-8401.

Available to the public from the National Technical Information Service, U.S. Department of Commerce, 5285 Port Royal Road, Springfield, VA 22161. 


\section{DISCLAIMER}

Portions of this document may be illegible electronic image products. Images are produced from the best available original document. 


\section{Table of Contents}

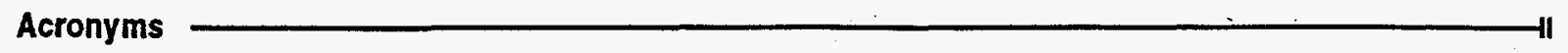

EXECUTIVE SUMMARY — 1

\section{SECTION}

I. INTRODUCTION AND BACKGROUND—_ 3

1. COMMUNITY INVOLVEMENT-

III. SCOPE AND ROLE OF OPERABLE UNIT (RESPONSE ACTION) WITHIN THE SITE STRATEGY-

IV. MEDIA SPECIFIC OPERABLE UNIT - THE GUNSITE 720 RUBBLE PIT UNIT—

IVA. Unit Description and Location, Unit History, and Media Assessment-

IVB. Operable Unil Risks___ 9

V. DESCRIPTION OF THE "NO ACTION" PREFERRED ALTERNATIVE-

REFERENCES - 10

\section{List of Figures}

1. Location of the Gunsite 720 Rubble Pit Unit in Relation to Major Savannah River Site Facilities

2. Layout of the Gunsite 720 Rubble Pit Unit Showing Sample Locations$-6$ and Location and Concentration of Metals Which Exceed the Unit-Background Level.

\section{Appendix}

A. Glossary A-1 
BRA Baseline Risk Assessment

CERCLA Comprehensive Environmental Response, Compensation, and Liability Act, 1980

DOE U.S. Department of Energy

EPA U. S. Environmental Protection Agency

FFA Federal Facility Agreement

RCRA Resource Conservation and Recovery Act, 1976

RFA RCRA Facility Assessment

RFI/RI RCRA Facility Investigation/Remedial Investigation

ROD Record of Decision

SCDHEC South Carolina Department of Health and Environmental Control

SRS Savannah River Site

WSRC Westinghouse Savannah River Company 


\section{EXECUTIVE SUMMARY}

This Statement of Basis/Proposed Plan for the Gunsite 720 Rubble Pit Unit is issued by the U. S. Department of Energy (DOE), the lead agency for the Savannah River Site (SRS) remedial activities, with concurrence by the U. S. Environmental Protection Agency (EPA) - Region IV, and the South Carolina Department of Health and Environmental Control (SCDHEC).

The purpose of this plan is to describe the preferred remedial alternative for addressing the Gunsite 720 Rubble Pit Unit located at SRS near Aiken, SC, and to provide an opportunity for public input into the remedial action selection process. Section 117 (a) of the Comprehensive Environmental Response, Compensation, -and Liability Act (CERCLA) and R.6179.124 of the South Carolina Hazardous Waste Management Regulations (SCHWMR) require publication of a notice of the proposed remedial actions (i.e., the Statement of Basis/Proposed Plan).

SRS manages certain waste materials which are regulated under RCRA, a comprehensive law, requiring responsible management of hazardous waste. RCRA 3004(u) requires that releases from solid waste management units be investigated and remediated as necessary. The Gunsite 720 Rubble Pit Unit is a solid waste management unit regulated under RCRA 3004(u).

The Gunsite 720 Rubble Pit Unit is located on the west side of SRS. It is approximately 305 meters (1000 feet) west of South Carolina Highway 125, 168 meters (550 feet) north of SRS Road A-2, and 2.5 kilometers (1.5) miles from the nearest SRS site boundary. The unit consists of an open area of approximately 2,250 square meters (25,000 square feet), is relatively flat, and is surrounded by native pine trees and shrubs. Two concrete slabs and an old water well are located on the east side of the open area.
During the period 1955 to 1960 , at SRS, the U. S. Army established various gunsites for anti-aircraft artillery gun emplacements to defend SRS in the event of an air attack. Gunsite 720 was one of those emplacements.

In the early to mid-1980s, nine empty, partially buried drums, labeled "duPont Freon 11", were found at Gunsite 720. As a result, Gunsite 720 became one of the original waste units specified in the SRS Resource Conservation and Recovery Act (RCRA) Facility Assessment (RFA). When SRS was included on the National Priorities List, Gunsite 720 became a RCRA/CERCLA unit, requiring further evaluation under an investigation/ assessment process that integrates the two programs.

The nine drums were excavated in July 1987, and placed on a pallet at Gunsite 720. In October 1989, the drums were removed from the site.

A review of SRS site plans and maps also indicated the presence of an underground fuel storage tank. An above-ground tank was also noted on the map. However, there is no physical evidence that indicates that the tank currently exists at the Gunsite 720 Rubble Pit Unit. Currently, the unit consists of two concrete slabs and an old water well.

The results of the RCRA Facility Investigation/ CERCLA Remedial Investigation (RFI/RI) Report (WSRC, 1996) indicate that the Gunsite 720 Rubble Pit Unit poses no threat to human health or the environment. There is no record of hazardous substances being managed at the unit. All the substances detected in the soil during sampling activities, conducted in 1990 and 1993, are at concentrations below EPA risk-based concentrations. Therefore, they pose no risk to human health or the environment. 
Based on the results of the RFI/RI Report (WSRC, 1996), DOE, EPA, and SCDHEC recommend that no remedial action be performed at the Gunsite 720 Rubble Pit Unit. No other alternatives were evaluated. There is no waste to treat and therefore, no institutional or engineering controls are required. The proposed no action alternative is intended to be the final action. No cleanup activities and no $\operatorname{cost}(s)$ would be involved.

Community involvement in the remedial alternative selection review process for the Gunsite 720 Rubble Pit Unit is strongly encouraged. Section II includes SRS contact information to request additional information about this Statement of Basis/Proposed Plan, or to submit comments. All submitted comments will be reviewed and considered prior to the final decision. A Responsiveness Summary will be prepared to address significant issues raised during the public comment period. The summary will be made available in the Record of Decision (ROD) and with the final RCRA permit. The ROD and RCRA permit document the final decision for the unit. 


\section{SECTION I. INTRODUCTION AND BACKGROUND}

\section{Introduction}

This Statement of Basis/Proposed Plan for the Gunsite 720 Rubble Pit Unit is issued by DOE, the lead agency for SRS remedial activities, with concurrence by EPA and SCDHEC. The purpose of this plan is to describe the preferred alternative for addressing the Gunsite 720 Rubble Pit Unit located on the west side of SRS near Aiken, $\mathrm{SC}$, and to provide for public involvement in the decision-making process.

SRS manages certain waste materials which are regulated under RCRA, a comprehensive law, requiring responsible management of hazardous waste. RCRA 3004(u) requires that releases from solid waste management units be investigated and remediated as necessary. The Gunsite 720 Rubble Pit Unit is a solid waste management unit regulated under RCRA 3004(u).

CERCLA public participation requirements are listed in Sections 113 and 117 of CERCLA. These requirements include establishment of an Administrative Record File that documents the selection of remedial alternatives and allows for review and comment by the public regarding those alternatives (see Section II). The Administrative Record File must be established "at or near the facility at issue." The SRS Public Involvement Plan (DOE, 1994) is designed to facilitate public involvement in the decision-making process for permitting, closure, and the selection of remedial alternatives. Section 117(a) of CERCLA requires publication of a notice of any proposed remedial action and provides the public an opportunity to participate in the selection of a remedial action.

RCRA provides opportunities for the public to comment on draft permit modifications. Public participation requirements are also listed in SCHWMR R.61-79.124 and require publication of the draft permit modifications. SCHWMR R.6179.124 requires a brief description and response to all significant comments be made available to the public as a part of the Administrative Record. The preferred alternative proposed in this Statement of Basis/Proposed Plan is also being proposed as a draft permit modification under RCRA. Therefore, any comments received on this Statement of Basis/Proposed Plan will also be applicable to the draft RCRA permit modification, proposing the same remedy for this waste unit.

This Statement of Basis/Proposed Plan is a summary of the Administrative Record File leading to selection of the preferred alternative. The Statement of Basis/Proposed Plan presents the preferred alternative and the rationale for selecting that alternative. Community involvement in consideration of the no action alternative for the Gunsite 720 Rubble Pit Unit is strongly encouraged. All submitted comments will be reviewed and considered.

Following the public comment period, a Responsiveness Summary will be prepared to address significant issues raised during the comment period. The Responsiveness Summary will be made available with the final RCRA permit modification and the ROD.

The final selection of the remedial alternative under RCRA will be in the form of a final permit modification decision which is made by SCDHEC. The final selection of the remedial alternative that will satisfy the FFA requirements, will be made by $\mathrm{DOE}$, in consultation with EPA and SCDHEC, only after the public comment period has ended and after all comments submitted have been reviewed and considered. 


\section{Background}

SRS occupies approximately 310 square miles of land adjacent to the Savannah River, principally in Aiken and Bamwell Counties of South Carolina SRS is a secured U. S. Government facility with no permanent residents. SRS is located approximately 25 miles southeast of Augusta, GA, and 20 miles south of Aiken, SC. Figure 1 shows the location of the Gunsite 720 Rubble Pit Unit in relation to other facilities at SRS and Figure 2 shows the layout of the unit with sample locations.

\section{SECTION II. COMMUNITY INVOLVEMENT}

This Statement of Basis/Proposed Plan summarizes information from the documents listed in the Reference Section of this document. These unabridged documents are part of the FFA Administrative Record File, which is available for review by the public at the following locations:

\section{U.S. Department of Energy \\ Public Reading Room \\ Gregg-Graniteville Library \\ University of South Carolina-Aiken \\ 171 University Parkway \\ Aiken, SC 29801 \\ (803) 641-3465}

Thomas Cooper Library

Government Documents Department

University of South Carolina

Columbia, SC 29208

(803) $777-4866$

Similar information is available through the repositories listed below:

Reese Library

Augusta State University

2500 Walton Way

Augusta, GA 30910

(706) $737-1744$
Asa H. Gordon Library -

Savannah State University

Thompkins Road

Savannah, GA 31404

(912) $356-2183$

The RCRA Administrative Record File for SCDHEC is available for review by the public at the following locations:

The South Carolina Department of Health and Environmental Control

Bureau of Solid and Hazardous Waste Management

8901 Farrow Road

Columbia, South Carolina 29203

(803) $896-4000$

Lower Savannah District

Environmental Quality Control Office

215 Beaufort St., NE

Aiken, SC 29802

(803) 648-9561

The public will be notified of a public comment period by mailing the SRS Environmental Bulletin, a newsletter sent to approximately 3500 citizens in South Carolina and Georgia, and through the Aiken Standard, the Allendale Citizen Leader, the Barnwell People-Sentinel, the State, and the Augusta Chronicle newspapers. The public comment period will also be announced on local radio stations. 


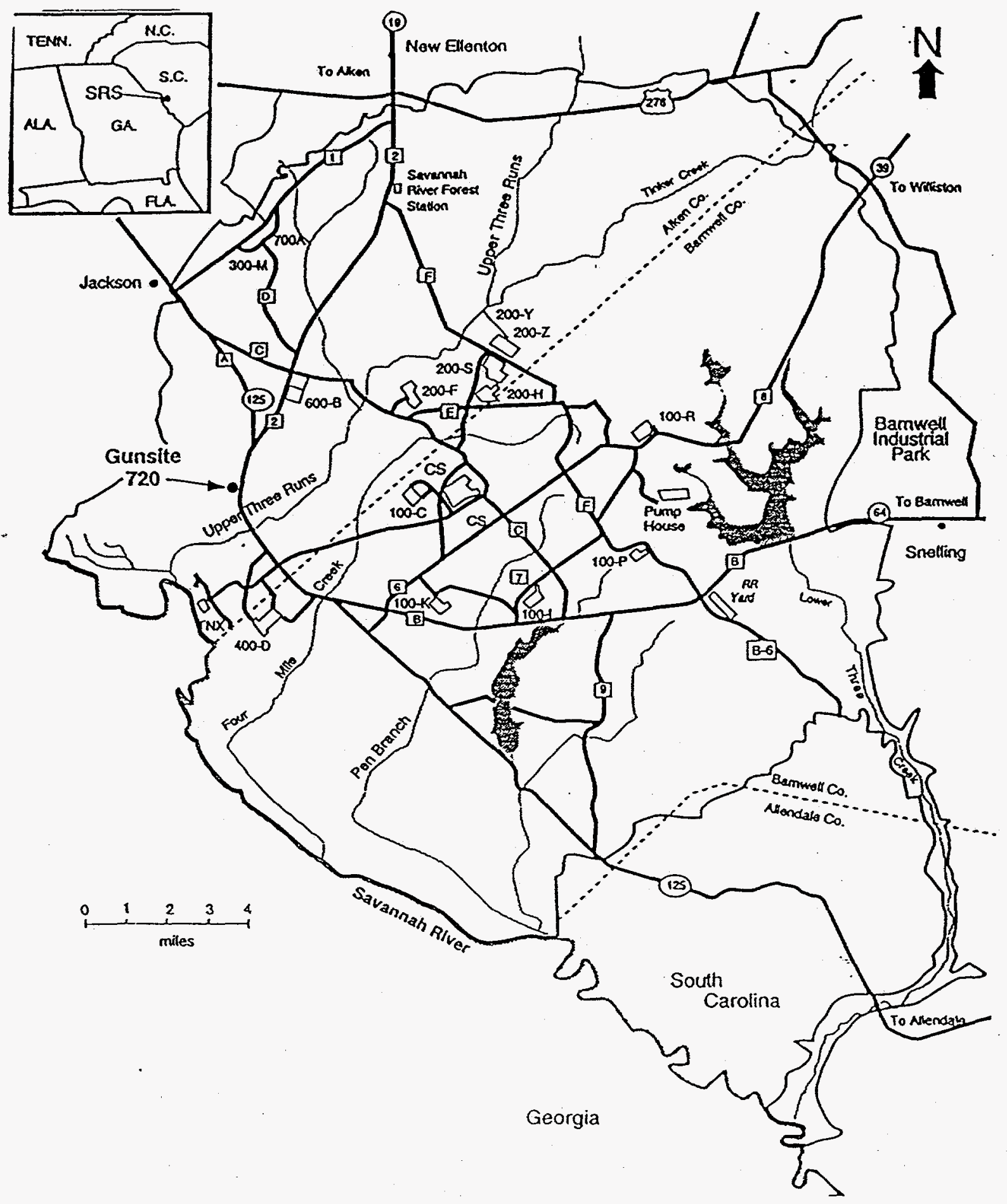

Figure 1. Location of the Gunsite 720 Rubble Pit Unit in Relation to Major SRS Facilities. 


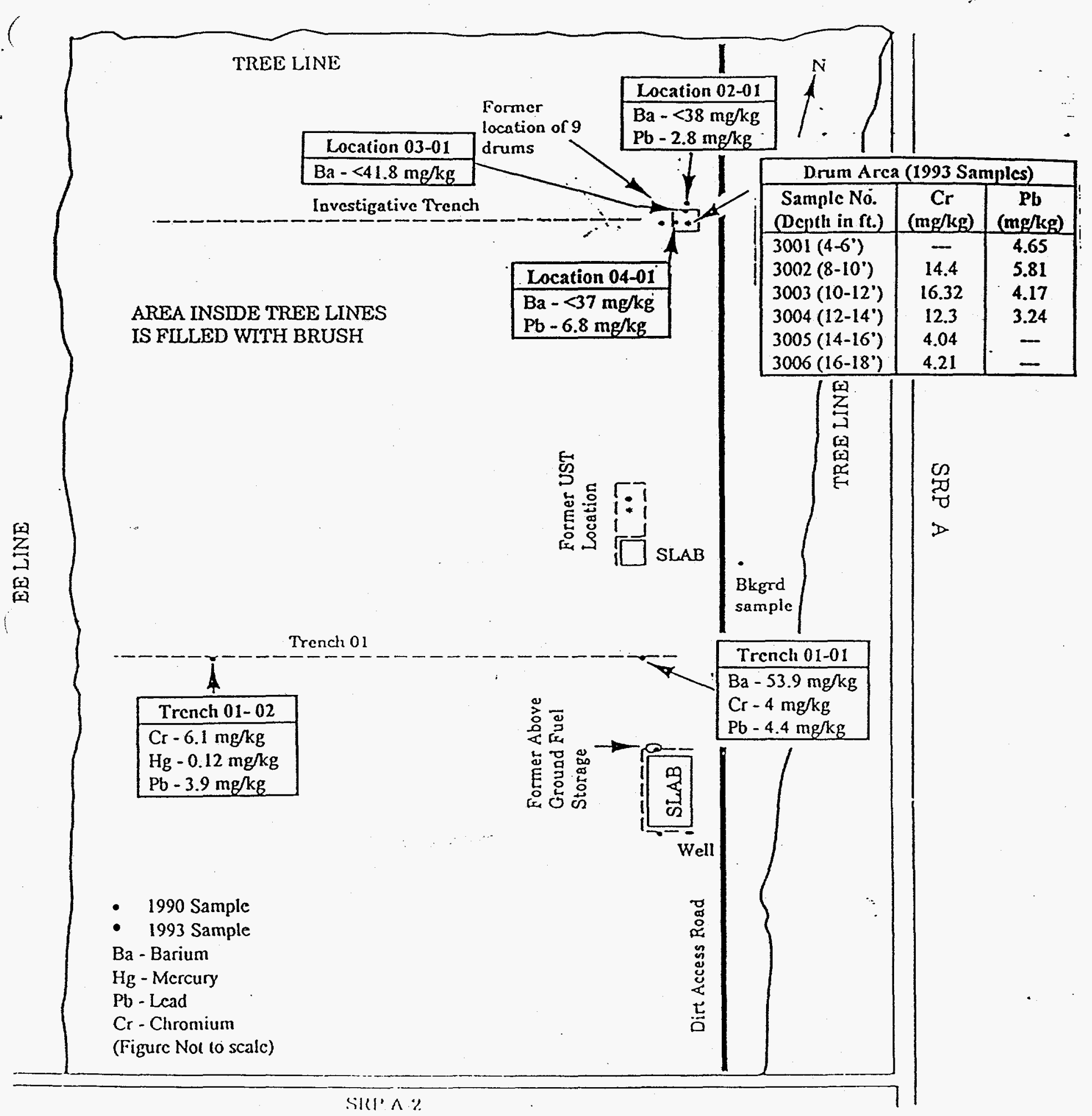

Figure 2. Layout of the Gunsite 720 Rubble Pit Unit Showing Sample Locations and Location and Concentration of Metals Which Exceed the Unit-Specific Background Level 
DOE will provide an opportunity for a public meeting during the public comment period, if interest is expressed. The public will be notified of the date, time, and location. At the meeting, the proposed action will be discussed and questions about the action will be answered.

To request a public meeting during the comment period, obtain more information concerning this Statement of Basis/Proposed Plan, or submit written comments, contact one of the following:

\section{A. Flora}

Public Involvement

Westinghouse Savannah River Company

Savannah River Site

Building 730-2B

Aiken, SC 29808

(803) 952-6852

The South Carolina Department of Health and Environmental Control

Bureau of Solid and Hazardous Waste Management

8901 Farrow Road

Columbia, South Carolina 29203

(803) 896-4000

Following the comment period, a ROD will be signed and a final decision for the RCRA Permit will be issued. The ROD and RCRA Permit will detail the alternative chosen for the site and will include responses to oral and written comments received during the public comment period in the Responsiveness Summary.

\section{SECTION III. SCOPE AND ROLE OF RESPONSE ACTION WITHIN THE SITE STRATEGY}

The Gunsite 720 Rubble Pit Unit is an operable unit located within the Upper Three Runs Creek watershed. In addition to the Gunsite 720 Operable Unit, there are many operable units located within the watershed. All the source control and groundwater operable units located within this watershed will be evaluated to determine their impacts, if any, to the associated streams and wetlands.

SRS will manage all source control units to prevent impact to the watershed. Upon disposition of all source control and groundwater operable units within this watershed, a final comprehensive ROD for the Upper Three Runs Creek watershed will be pursued.

The field investigations and soil sampling conducted during 1990 and 1993 indicated that there are no hazardous substances at the Gunsite 720 Rubble Pit Unit that would impact the groundwater.

\section{SECTION IV. MEDIA SPECIFIC OPERABLE UNIT - THE GUNSITE 720 RUBBLE PIT UNIT}

\section{Section IVA. Unit Description and Location, Unit History, and Media Assessment}

\section{Unit Description and Location}

The Gunsite 720 Rubble Pit Unit is located within SRS and is approximately 305 meters (1000 feet) west of South Carolina Highway 125, 168 meters (550 feet) north of SRS Road A-2, and 2.5 kilometers ( 1.5 miles) from the nearest SRS boundary (see Figure 1). The topography of the area is relatively flat with an elevation of about 150 feet above mean sea level. The unit consists of an open area covered with natural shrub growth and surrounded by native pine trees. The unit encompasses an area of approximately 2,250 square meters $(25,000$ square feet). Two concrete slabs and an abandoned well are located on the east side of the unit (see Figure 2). Surface drainage in the area is to Upper Three Runs Creek, approximately 1,200 meters (4000 feet) south of the unit. The water table in the area is approximately 10 feet below ground surface. 


\section{Unit History}

During the period from 1955 to 1960 , to defend SRS in the event of an air attack, the U.S. Army established onsite anti-aircraft artillery gun emplacements at several locations near the perimeter of SRS. Gunsite 720 was one of those emplacements. There is no documentation or record of any hazardous substance management or disposal at this unit. There is no evidence that any recent disposal activity has occurred. Also, there is no evidence of any burning or excavation at this waste unit.

In the early to mid 1980 s, while work was being performed in the area, nine (9) empty, partially buried drums, labeled "duPont Freon 11", were found at the gunsite. The drums were excavated in July 1987, and placed on a pallet at the gunsite. In October 1989, the drums were removed from the unit. The area around the drums was screened during excavation and the liquid (rainwater) that collected in the excavated drums was sampled prior to disposal. No evidence of hazardous substances was found.

A review of SRS plans and maps indicated that an underground fuel storage tank was at the gunsite. An above-ground tank was also noted on the maps. However, there is no physical evidence that the tank still exists at this unit. Currently, the unit consists of two concrete slabs and an old well. No contamination, other than isolated pods of household trash (bottles, wrappers, etc.), were noted in the area.

\section{Media Assessment}

The RFI/RI Plan (WSRC, 1990) and RFI/RI Report (WSRC, 1996) contain detailed information and analytical data for all the investigations conducted and samples taken in the media assessment of the Gunsite 720 Rubble Pit Unit. These documents are available in the Administrative Record File (see Section II of this document).
Preliminary investigations pertaining to the Gunsite 720 Rubble Pit Unit were conducted in March 1988 (Looney, et al. 1988) and consisted of four soil gas samples near the former location of the nine 30-gallon empty drums found in the early 1980s. The samples were analyzed for chlorinated hydrocarbons. No chlorinated hydrocarbons (chlorinated solvents) were detected.

In 1986, a magnetic survey was conducted to locate underground tank(s) believed to be buried at the unit. However, the results of the magnetometer survey were inconclusive. In March 1989, a ground penetrating radar survey was conducted. The survey indicated that there were no buried or underground objects in the area. Trenches were also excavated at the unit to visually characterize buried waste and to locate and identify any underground storage tanks that might be present (see Figure 2). No evidence of burial pits was found. All trenches were backfilled with the excavated materials and leveled.

\section{SOILS}

During 1990, 12 soil samples (including one background sample) were obtained from various locations within the Gunsite 720 Rubble Pit Unit area and one background location (see Figure 2). Soil samples were taken from depth intervals of 0-0.9 meters ( $0-3$ feet) and 1.8-2.4 meters

(6-8 feet) below the ground surface.

Samples were sent to an offsite laboratory for analysis and were analyzed in accordance with EPA contract laboratory program (CLP) approved protocols.

The only hazardous substances detected that exceeded their respective unit-specific background concentrations were: barium, $53.9 \mathrm{mg} / \mathrm{kg}$; chromium, $6.1 \mathrm{mg} / \mathrm{kg}$; lead, 6.8 $\mathrm{mg} / \mathrm{kg}$; and total mercury, $0.12 \mathrm{mg} / \mathrm{kg}$. However, the concentrations detected for all the four hazardous substances were below their respective EPA risk-based concentration levels. 
Based on comparison of analytical results to risk-based concentrations and two times unit-specific concentrations, it was evident that there had been no environmental impact due to hazardous substance disposal at or release from the Gunsite 720 Rubble Pit Unit.

\section{Additional Investigations and Soil Sampling}

In early 1993, SCDHEC expressed some concerns regarding the existence of the underground storage tanks at the unit and potential releases from the tanks and the drums that were located at the Gunsite 720 Rubble Pit Unit. SRS performed additional ground penetrating radar and magnetometer surveys, and also obtained additional soil samples from the areas where the drums had been found and the underground storage tank was believed to have been located. Samples were collected at various depths ranging from 1.2 meters (4 feet) down to 5.5 meters (18 feet). Figure 2 shows the locations of samples collected in the 1993 survey.

The ground penetrating radar and magnetometer surveys did not indicate the existence of an underground storage tank or any other buried debris. It was concluded that the tank had been removed.

No hazardous substances were detected in the underground storage tank area. Barium, chromium, lead, and trace levels of $1,1,1$ trichloroethane $(0.028 \mathrm{mg} / \mathrm{kg})$ in some samples were detected in the drum area. Petroleum hydrocarbons were not detected at all in the soil samples. The maximum concentration of barium detected was $30.7 \mathrm{mg} / \mathrm{kg}$; well below the maximum concentration $(53.9 \mathrm{mg} / \mathrm{kg})$ detected during 1990 investigations. The maximum concentration of chromium detected was $16.32 \mathrm{mg} / \mathrm{kg}$. The maximum concentration of lead detected $(5.81 \mathrm{mg} / \mathrm{kg})$ was also lower than the maximum concentration $(6.8 \mathrm{mg} / \mathrm{kg})$ found in the 1990 sampling.
Hence, the only metal detected in 1993 sampling exceeding the 1990 maximum concentration is chromium. However, this concentration is significantly less than EPA risk-based concentrations for chromium (for $\mathrm{Cr}^{+6}$ and $\mathrm{Cr}^{+3}$ ).

\section{Groundwater}

Since preliminary investigations conducted in 1988 and soil samples collected in $\mathbf{1 9 9 0}$ and 1993 concluded that there was no evidence of contamination, no groundwater monitoring wells were installed at this unit, and no groundwater data were collected.

\section{Section IVB. Operable Unit Risks}

\section{Human Health Risk Assessment}

A review of the analytical data for the Gunsite 720 Rubble Pit Unit indicated that the data are of sufficient quality for use in the unit risk assessment evaluation. An evaluation was conducted to estimate the human health and environmental problems that could result from the no action decision. The results indicated that the concentrations of all hazardous materials analyzed were below any EPA risk-based concentration action levels.

Based on the analytical data, there are no contaminants of potential concern for evaluation in a CERCLA baseline risk assessment (BRA) and, hence, there is no determinable risk associated with the Gunsite 720 Rubble Pit Unit.

\section{Ecological Risk Assessment}

Based on the physical and analytical data pertaining to this unit, there is no evidence that waste materials were managed or disposed at the Gunsite 720 Rubble Pit Unit. Therefore, it is reasonable to conclude that this unit presents no significant ecological risk. A further detailed ecological risk assessment and characterization is not warranted. 


\section{SECTION V. DESCRIPTION OF THE "NO ACTION" PREFERRED ALTERNATIVE}

Based on the unit characterization and risk assessment, the Gunsite 720 Rubble Pit Unit poses no risk to human health and the environment. Therefore, the unit requires no cleanup activities and the no action alternative is recommended for this unit. No additional alternatives were considered for evaluation.

The no action alternative means that no remedial action will be performed at the Gunsite 720 Rubble Pit Unit. There is no waste to treat, no institutional or engineering controls are required, and there are no applicable or relevant and appropriate requirements (ARARs). Because no further action would be taken, the Gunsite 720 Rubble Pit Unit would remain in its present condition. No costs will be involved for this action.

Since the Gunsite 720 Rubble Pit Unit poses no risk to human health or the environment and no action is warranted at this unit, it satisfies CERCLA criteria. The no action altemative will be the final action for the Gunsite 720 Rubble Pit Unit and there will be no five-year (ROD) reviews. This solution is meant to be permanent and effective in both the long and short term.

This Proposed Plan provides for community involvement through a document review process and a public comment period. Public input will be documented in the responsiveness summary section of the ROD.

\section{REFERENCES}

DOE (U. S. Department of Energy), 1994, Public Involvement, A Plan for the Savannah River Site, Savannah River Operations Office, Aiken, SC.

Federal Facility Agreement, 1993, Federal Facility Agreement for the Savannah River Site, Administrative Docket No. 89-05-FF, (Effective Date: August 16, 1993).

Looney, B. B., et al., 1988, Soil Gas Surveys at Selected Potential Waste Sites at the Savannah River Site, DPST-88-619, E. I. du Pont de Nemours and Company, Savannah River Laboratory, Aiken, SC.

WSRC, 1990, RCRA Facility Investigation/Remedial Investigation Plan for the Gunsite 720 Rubble Pit Unit, WSRC-RP-90-1049, Westinghouse Savannah River Company, Aiken, SC.

WSRC, 1996, RCRA Facility Investigation/Remedial Investigation Report for the Gunsite 720 Rubble Pit Unit (63116G) (U), WSRC-RP-95-360, Rev 1, Westinghouse Savannah River Company, Aiken, SC. 


\section{APPENDIX A. GLOSSARY}

Administrative Record File: A file that is maintained and contains all information used to make a decision on the selection of response action under the Comprehensive Environmental Response, Compensation, and Liability Act. This file is to be available for public review, and a copy is to be established at or near the Site, usually at one of the information repositories. Also, a duplicate file is held in a central location, such as a regional or state office.

Applicable or Relevant and Appropriate Requirements (ARARs): ARARs refer to the Federal and state requirements that a selected remedy will attain. These requirements may vary from site to site.

Baseline Risk Assessment (BRA): An analysis of the potential adverse health effects (current or future) caused by hazardous substance release from a site in the absence of any actions to control or mitigate these releases.

Characterization: The compilation of all available data about waste units to determine the rate and extent of contaminant migration resulting from the waste site, and the concentration of any contaminants that may be present.

Comprehensive Environmental Response, Compensation, and Liability Act (CERCLA), 1980: A federal law passed in 1980 and modified in 1986 by the Superfund Amendments and Reauthorization Act. The act created a special tax that goes into a Trust Fund, commonly known as Superfund, to investigate and cleanup abandoned or uncontrolled hazardous waste sites.

Exposure: Contact of an organism with a chemical or physical agent. Exposure is quantified as the amount of the agent available at the exchange boundaries of the organism (e.g., skin, lungs, digestive tract) and available for absorption.
Federal Facility Agreement (FFA): A legally binding agreement between regulatory agencies (EPA and SCDHEC) and regulated entities (DOE) that sets standards and schedules for compliance with environmental laws.

Ground Penetrating Radar (GPR): A technique involving the recording and displaying of reflected radio frequency energy to evaluate soil, structures, and waste buried objects.

Magnetometer: A device used to locate buried metallic objects which create a measurable disturbance in the magnetic field of the earth.

Media: A pathway through which contaminants are transferred. Five media by which contaminants may be transferred are: groundwater, soil, surface water, sediments, and air.

Milligram per Kilogram: A unit of measure of concentration equivalent weight/mass ratio expressed as $\mathrm{mg} / \mathrm{kg}$ or parts per million (ppm).

National Priorities List (NPL): Formal listing of the nation's worst contaminated sites, as established by the Comprehensive Environmental Response, Compensation, and Liability Act.

Operable Unit: A discrete action taken as one part of an overall site cleanup. The term is also used in EPA guidance documents to refer to distinct geographic areas or mediaspecific units within a site. A number of operable units can be used in the course of a cleanup.

Record of Decision (ROD): A legal document that describes the final remedial actions selected for a Superfund site, why the remedial actions were chosen and not others, how much they will cost, and how the public responded to the proposed remedial actions. 
Resource Conservation and Recovery Act (RCRA), 1976:. What is commonly referred to as RCRA is an amendment to the first pieces of federal solid waste legislation called the Solid Waste Disposal Act of 1965. RCRA was amended in 1980 and on November 8, 1984 by the Hazardous and Solid Waste Amendments (HSWA).

\section{Resource Conservation and Recovery} Act (RCRA) Facility Investigation/Remedial Investigation (RFI/RI): Investigation conducted at a waste site to determine the extent and magnitude of a hazardous substance release from the waste site to any environmental media. Information generated in the investigation is used in the BRA; the results of the investigation are documented in the RFI/RI Report.
Responsiveness Summary: A summary of oral and/or written public comments received during the proposed plan comment period and includes responses to those comments. The responsiveness summary is a key part of the ROD, documenting community concerns.

Statement of Basis/Proposed Plan (PP): A legal document that provides a brief analysis of remedial alternatives under consideration for the site/operable unit and proposes the preferred alternative. It actively solicits public review and comment on all alternatives under consideration. 